\title{
Optimization and partial characterization of culture conditions for the production of alkaline protease from Bacillus licheniformis P003
}

\author{
Palash Kumar Sarker ${ }^{1 *}$, Saimon Ahmad Talukdar², Promita Deb², SM Abu Sayem² and Kaniz Mohsina ${ }^{2}$
}

\begin{abstract}
Proteolytic enzymes have occupied a pivotal position for their practical applications. The present study was carried out under shake flask conditions for the production of alkaline protease from Bacillus licheniformis P003 in basal medium containing glucose, peptone, $\mathrm{K}_{2} \mathrm{HPO}_{4}, \mathrm{MgSO}_{4}$ and $\mathrm{Na}_{2} \mathrm{CO}_{3}$ at $\mathrm{pH} 10$. The effect of culture conditions and medium components for maximum production of alkaline protease was investigated using one factor constant at a time method along with its characterization. Maximum level of enzyme production was obtained after $48 \mathrm{~h}$ of incubation with $2 \%$ inoculum size at $42^{\circ} \mathrm{C}$, under continuous agitation at $150 \mathrm{rpm}$, in growth medium of pH 9 . Highest enzyme production was obtained using $1 \%$ rice flour as carbon source and $0.8 \%$ beef extract as organic nitrogen source. Results indicated that single organic nitrogen source alone was more suitable than using in combinations and there was no significant positive effect of adding inorganic nitrogen sources in basal medium. After optimization of the parameters, enzyme production was increased about 20 fold than that of in basal medium. The crude enzyme was highly active at pH 10 and stable from pH 7-11. The enzyme showed highest activity $(100 \%)$ at $50^{\circ} \mathrm{C}$, and retained $78 \%$ relative activity at $70^{\circ} \mathrm{C}$. Stability studies showed that the enzyme retained $75 \%$ of its initial activity after heating at $60^{\circ} \mathrm{C}$ for $1 \mathrm{~h}$. The enzyme retained about $66 \%$ and $46 \%$ of its initial activity after 28 days of storage at $4^{\circ} \mathrm{C}$ and room temperature $\left(25^{\circ} \mathrm{C}\right)$ respectively. $\mathrm{Mn}^{2+}$ and $\mathrm{Mg}^{2+}$ increased the residual activity of the enzyme, whereas $\mathrm{Fe}^{2+}$ moderately inhibited its residual activity. When pre-incubated with Tween-20, Tween-80, SDS and $\mathrm{H}_{2} \mathrm{O}_{2}$, each at $0.5 \%$ concentration, the enzyme showed increased residual activity. These characteristics may make the enzyme suitable for several industrial applications, especially in leather industries.
\end{abstract}

Keywords: Bacillus licheniformis; Alkaline protease; Shake flask culture; Production optimization

\section{Background}

Proteases execute a large variety of functions and have numerous applications in detergent, food, pharmaceutical and leather industries (Gupta et al. 2002). Alkaline proteases hold a major share of the enzyme market with two third shares in detergent industry alone (Anwar and Saleemuddin 2000, Haki and Rakshit 2003). Although there are many microbial sources available for protease production, only a few are considered as commercial producers (Beg et al. 2002). Of these, species of Bacillus dominate in the industry (Gupta et al. 2002). Due to enhancement of such demand of proteases for specific

\footnotetext{
* Correspondence: palashnib@yahoo.com

'Microbial Biotechnology Division, National Institute of Biotechnology, Savar, Dhaka, Bangladesh

Full list of author information is available at the end of the article
}

properties, scientists are looking for newer sources of proteases. In addition, for effective use in industries, alkaline proteases need to be stable and active at high temperature and $\mathrm{pH}$ and in the presence of surfactants, oxidizing agents, and organic solvents (Johnvesly and Naik 2001, Fu et al. 2003, Rahman et al. 2006, Bhunia et al. 2011). Culture condition is also another important parameter to consider that can influence the cost and rate of enzyme production (Beg et al. 2002). About 30$40 \%$ of the cost of industrial enzymes depends on the cost of the growth medium (Joo et al. 2003). In addition, extracellular protease production from Bacillus species is significantly influenced by medium composition and some physical factors, such as fermentation period, aeration, inoculum density, incubation temperature and $\mathrm{pH}$ of growth medium (Puri et al. 2002; Genckal and Tari 
2006; Nadeem et al. 2006). In this study, strategies were applied to optimize the production of alkaline protease from Bacillus licheniforms P003. The enzyme was also partially characterized in this study.

\section{Results and discussion}

The demand of eco-friendly technology is increasing day by day to reduce the pollution at industrial level. Being an eco-friendly compound, enzymes got application at different industrial sectors. There is no general medium for protease production by different microbial strains (Pandey et al. 2000). Every microorganism evidences its own idiosyncratic physicochemical and nutritional requirements for growth and enzyme secretion (Reddy et al. 2008). Enzyme production was carried out under shake flask culture at $37^{\circ} \mathrm{C}$ and $150 \mathrm{rpm}$ for the production of alkaline protease from B. licheniformis P003 in basal medium containing Glucose 10.0 g/l, Peptone 10.0 g/l, K2HPO4 1.0 g/l, MgSO4 $0.2 \mathrm{~g} / \mathrm{l}, \mathrm{Na} 2 \mathrm{CO} 35.0 \mathrm{~g} / \mathrm{l}$ at initial $\mathrm{pH}$ 10. After $48 \mathrm{~h}$ fermentation, enzyme activity of $46.10 \mathrm{U} / \mathrm{ml}$ was obtained. To increase the production of enzyme, optimization of culture conditions and medium components were then studied. Initially, the traditional one-fact-at-a-time method was employed for selection of appropriate medium ingredients and their apparent concentrations of the enzyme production.

The initial $\mathrm{pH}$ of the culture media has an intense effect on protease production. It was found that $B$. licheniformis $\mathrm{P} 003$ was capable of producing alkaline protease over a wide range of initial culture $\mathrm{pH}$ (8.510.5), but the enzyme production was found to be highest $(89.30 \mathrm{U} / \mathrm{ml})$ at $\mathrm{pH} 9.0$. The enzyme production was drastically reduced at pH 12.0 (Table 1). In order to assess the effect of temperature on protease production, fermentation was carried out at different temperatures ranges from $32^{\circ} \mathrm{C}$ to $45^{\circ} \mathrm{C}$. The effect of temperature on alkaline protease production revealed that maximum yield $(54.12 \mathrm{U} / \mathrm{ml})$ was obtained at $42^{\circ} \mathrm{C}$ after $48 \mathrm{~h}$ of incubation. The maximum extracellular soluble protein was also found at $42^{\circ} \mathrm{C}$. Appreciable amount of enzyme production occurred at temperatures ranging from 37 to $42^{\circ} \mathrm{C}$. A decrease in enzyme yield was observed with further increase in temperature (Table 1).

B. licheniformis P003 was cultivated in basal medium at $\mathrm{pH} 10.0$ for different incubation period ranging from 24 to 120 hours at a temperature of $37^{\circ} \mathrm{C}$ and $150 \mathrm{rpm}$ and enzyme assay was carried out every 24 hours interval. The time course data revealed that maximum level of alkaline protease was produced $(48.10 \mathrm{U} / \mathrm{ml}$ enzyme activity and $1.178 \mathrm{mg} / \mathrm{ml}$ protein concentration) after $48 \mathrm{~h}$ of cultivation period (Table 1). Xiong et al. (2010) found maximum protease production by $B$. licheniformis after $48 \mathrm{~h}$ of incubation. Olajuyigbe and Ajele (2008) also found maximum protease production of $18.4 \mathrm{U} / \mathrm{ml}$ after
$48 \mathrm{~h}$ incubation by B. licheniformis LBBL-11. Whereas, Akcan (2012) found highest alkaline protease production after $24 \mathrm{~h}$ by $B$. licheniformis ATCC 12759. Inoculum concentration was also studied for maximum alkaline protease production. According to data presented in Table 1, optimum concentration of inoculum for protease production was found at $2.0 \%$. Protease production was sharply decreased at a concentration of $2.5 \%$. Total protein content was also highest at $2.0 \%$ inoculum concentration.

To investigate the effect of different carbon sources on alkaline protease production by B. licheniformis P003, glucose of the basal media was replaced by equal amount of complex or simple carbon sources. It was observed that rice flour showed highest protease production followed by wheat bran and rice bran respectively (Table 2). When compared with control $(52.14 \mathrm{U} / \mathrm{ml})$, there was significant increase in enzyme yield in the case of the supplementation of rice flour $(491.92 \mathrm{U} / \mathrm{ml})$ and wheat bran $(327.14 \mathrm{U} / \mathrm{ml})$ as complex carbon sources. Similar effect of rice flour on protease production was observed by. Srividya and Mala (2011). Akcan (2012) found significant increase in enzyme yield in case of rice flour and wheat flour. In Bacillus strains such as $B$. licheniformis ATCC 21415 (Mabrouk et al. 1999), however, enhanced protease yields were reported on supplementation of glucose. Different concentrations of rice flour ranging from 0.5 to $3.0 \%$ were tested for maximum induction of enzyme. Maximum production occurs at $1.0 \%$ concentration and after that the production decreases as concentration increases (Figure 1).

The effect of different nitrogen sources in the form of organic or inorganic on alkaline protease production was also studied to identify the suitable nitrogen source, because the requirement for specific nitrogen source differs from organism to organism (Kumar and Takagi, 1999). Maximum yield (191.23 U/ml) was obtained in case of beef extract at initial concentration of $0.8 \%$ followed by yeast extract (Table 3). No significant effect was observed on protease production when combinations of different organic nitrogen sources were used at a concentration of $0.5 \%+0.5 \%$ (Table 3 ). Results indicated that single organic nitrogen source was more suitable than using them in combinations. Hossain et al. (2007) also reported that mixture of nitrogen sources were not effective to increase the production of protease by $B$. licheniformis MZK-3. These findings are in good agreement with Naidu and Devi (2005), who also reported maximum enzyme production in case of beef extract followed, by yeast extract. Whereas, Nadeem et al. (2008) reported maximum yield of enzyme in case of yeast extract followed by peptone. Nejad et al. (2009) reported that a mixture of peptone and yeast extract $(0.5 \%, 0.5 \%)$ were the best nitrogen sources for protease 
Table 1 Effect of culture conditions for production of extracellular protease from B. licheniformis P003 in shake-flask cultivation

\begin{tabular}{|c|c|c|c|c|}
\hline Culture condition & $\begin{array}{l}\text { Protease activity }(\mathrm{U} / \mathrm{ml}) \\
\qquad \text { Mean } \pm \mathrm{SE}\end{array}$ & $\begin{array}{l}\text { Relative } \\
\text { activity } \\
(\%)\end{array}$ & $\begin{array}{l}\text { Protease activity (U/mg) } \\
\text { Mean } \pm \text { SE }\end{array}$ & $\begin{array}{c}\text { Total soluble protein }(\mathrm{mg} / \mathrm{ml}) \\
\text { Mean } \pm \text { SE }\end{array}$ \\
\hline \multicolumn{5}{|l|}{ Initial pH } \\
\hline 8.0 & $39.01 \pm 0.190$ & 43.68 & $43.72 \pm 1.22$ & $0.889 \pm 0.021$ \\
\hline 8.5 & $81.28 \pm 0.199$ & 91.02 & $86.13 \pm 2.12$ & $0.944 \pm 0.021$ \\
\hline 9.0 & $89.30 \pm 0.661$ & 100.00 & $104.10 \pm 1.53$ & $0.858 \pm 0.016$ \\
\hline 9.5 & $79.38 \pm 0.143$ & 88.89 & $83.81 \pm 1.51$ & $0.947 \pm 0.016$ \\
\hline 10.0 & $80.55 \pm 0.194$ & $90 . .20$ & $94.41 \pm 1.45$ & $0.853 \pm 0.015$ \\
\hline 10.5 & $74.62 \pm 0.562$ & 83.56 & $90.70 \pm 5.48$ & $0.825 \pm 0.057$ \\
\hline 11.0 & $10.91 \pm 0.185$ & 12.22 & $14.74 \pm 0.09$ & $0.74 \pm 0.010$ \\
\hline \multicolumn{5}{|c|}{ Incubation temperature $\left({ }^{\circ} \mathrm{C}\right)$} \\
\hline 32 & $39.08 \pm 0.096$ & 72.21 & $35.33 \pm 0.11$ & $1.106 \pm 0.006$ \\
\hline 35 & $45.10 \pm 0.070$ & 83.33 & $40.60 \pm 0.40$ & $1.112 \pm 0.013$ \\
\hline 37 & $48.71 \pm 0.026$ & 90.00 & $42.42 \pm 0.22$ & $1.143 \pm 0.014$ \\
\hline 40 & $50.19 \pm 0.053$ & 92.74 & $43.16 \pm 0.49$ & $1.155 \pm 0.023$ \\
\hline 42 & $54.12 \pm 0.056$ & 100.00 & $43.10 \pm 0.27$ & $1.255 \pm 0.007$ \\
\hline 45 & $43.90 \pm 0.098$ & 81.12 & $35.17 \pm 0.20$ & $1.247 \pm 0.010$ \\
\hline \multicolumn{5}{|l|}{ Incubation period (hr) } \\
\hline 24 & $9.62 \pm 0.062$ & 20.00 & $7.80 \pm 0.07$ & $1.231 \pm 0.008$ \\
\hline 48 & $48.10 \pm 0.062$ & 100.00 & $40.74 \pm 0.17$ & $1.178 \pm 0.008$ \\
\hline 72 & $36.68 \pm 0.046$ & 76.26 & $30.51 \pm 0.12$ & $1.200 \pm 0.007$ \\
\hline 96 & $34.27 \pm 0.072$ & 71.25 & $29.92 \pm 0.11$ & $1.143 \pm 0.007$ \\
\hline 120 & $22.85 \pm 0.046$ & 47.51 & $20.00 \pm 0.04$ & $1.141 \pm 0.005$ \\
\hline \multicolumn{5}{|c|}{ Inoculums volume (\%, ml) } \\
\hline 0.5 & $13.89 \pm 0.026$ & 25.95 & $16.31 \pm 0.09$ & $0.849 \pm 0.008$ \\
\hline 1.0 & $35.48 \pm 0.026$ & 66.29 & $41.51 \pm 0.20$ & $0.853 \pm 0.006$ \\
\hline 1.5 & $36.68 \pm 0.053$ & 68.54 & $43.12 \pm 0.17$ & $0.848 \pm 0.008$ \\
\hline 2.0 & $53.52 \pm 0.030$ & 100.00 & $58.54 \pm 0.37$ & $0.915 \pm 0.006$ \\
\hline 2.5 & $19.24 \pm 0.036$ & 35.95 & $27.15 \pm 0.38$ & $0.709 \pm 0.009$ \\
\hline 3.0 & $13.23 \pm 0.026$ & 24.72 & $19.23 \pm 0.17$ & $0.689 \pm 0.008$ \\
\hline 3.5 & $12.38 \pm 0.035$ & 53.03 & $23.31 \pm 0.39$ & $0.531 \pm 0.010$ \\
\hline
\end{tabular}

Data represent as mean \pm standard error (SE) for three replicates.

production by $B$. licheniformis BBRC 100053 . But, in the present study, lowest production was found when mixture of peptone and yeast extract was used in the basal medium.

Low activity $(4.81 \mathrm{U} / \mathrm{ml}$ and $9.62 \mathrm{U} / \mathrm{ml})$ was found in case of $\mathrm{NH}_{4} \mathrm{NO}_{3}$ and $\mathrm{KNO}_{3}$ respectively while highest activity $(49.31 \mathrm{U} / \mathrm{ml})$ was found when $\left(\mathrm{NH}_{4}\right)_{2} \mathrm{SO}_{4}$ was used as sole inorganic nitrogen source (Figure 2). When inorganic nitrogen salts were used in the basal medium as sole nitrogen source at a concentration of $1 \%$, maximum enzyme production was obtained by $\left(\mathrm{NH}_{4}\right)_{2} \mathrm{SO}_{4}$. However, Bhunia et al. (2010) found maximum production in case of sodium nitrate at a concentration of $0.5 \%$ followed by potassium nitrate, ammonium chloride, ammonium nitrate and ammonium sulfate respectively. Many other researchers have also reported that organic nitrogen source was better for enzyme production than inorganic (Feng et al. 2001; Joo et al. 2003).

Alkaline protease production was significantly increased about 20 fold $(930.02 \mathrm{U} / \mathrm{ml})$ using the simulated media after optimization of different parameters in comparison to the basal medium $(46.10 \mathrm{U} / \mathrm{ml})$.

The activity of the protease towards casein at different $\mathrm{pH}$ levels was determined. It can be observed from the figure (Figure 3) that protease was active between $\mathrm{pH}$ 7.5 and 11.0 and optimum at $\mathrm{pH} 10$. The relative activities at $\mathrm{pH} 7.5$ and 11.0 were found to be $74.54 \%$ and $87.40 \%$ of the activity found at $\mathrm{pH} 10$ respectively. The 
Table 2 Depicting the protease activity and total soluble protein of the culture supernatant of B. licheniformis P003 grown on different carbon source in presence of $1 \%$ peptone

\begin{tabular}{|c|c|c|c|}
\hline Carbon sources & $\begin{array}{l}\text { Protease activity }(\mathrm{U} / \mathrm{ml}) \\
\text { Mean } \pm \mathrm{SE}\end{array}$ & $\begin{array}{c}\text { Protease activity (U/mg) } \\
\text { Mean } \pm \text { SE }\end{array}$ & $\begin{array}{c}\text { Total protein content }(\mathrm{mg} / \mathrm{ml}) \\
\text { Mean } \pm \mathrm{SE}\end{array}$ \\
\hline Wheat flour & $120.87 \pm 0.046$ & $78.90 \pm 0.35$ & $1.530 \pm 0.008$ \\
\hline Wheat bran & $327.14 \pm 0.056$ & $167.22 \pm 0.22$ & $1.955 \pm 0.004$ \\
\hline Rice flour & $491.92 \pm 0.072$ & $344.40 \pm 0.46$ & $1.426 \pm 0.006$ \\
\hline Rice bran & $267.61 \pm 0.075$ & $142.83 \pm 0.33$ & $1.872 \pm 0.006$ \\
\hline Corn flour & $91.40 \pm 0.070$ & $65.61 \pm 0.08$ & $1.395 \pm 0.006$ \\
\hline Starch & $85.39 \pm 0.036$ & $59.13 \pm 0.17$ & $1.442 \pm 0.007$ \\
\hline Maltose & $24.05 \pm 0.082$ & $22.65 \pm 0.08$ & $1.059 \pm 0.008$ \\
\hline Lactose & $10.82 \pm 0.062$ & $11.36 \pm 0.12$ & $0.951 \pm 0.006$ \\
\hline Fructose & $55.92 \pm 0.062$ & $62.39 \pm 0.24$ & $0.894 \pm 0.006$ \\
\hline Control (Glucose) & $52.14 \pm 0.056$ & $60.96 \pm 0.29$ & $0.853 \pm 0.007$ \\
\hline
\end{tabular}

Data represent as mean \pm standard error $(\mathrm{SE})$ for three replicates.

enzyme was found stable over a broad $\mathrm{pH}$ range 6.5 to12.0 and higher stability was observed in the range of 7.5-8.5 (Figure 4).

The protease was found most active between temperature $50^{\circ} \mathrm{C}$ and $65^{\circ} \mathrm{C}$ and optimum at $50^{\circ} \mathrm{C}$ (Figure 5). The enzyme retained $87 \%$ and $70 \%$ of residual activity after 60 minutes of incubation at $50^{\circ} \mathrm{C}$ and $60^{\circ} \mathrm{C}$ respectively (Figure 6). Yu et al. (2006) also reported that enzyme from $B$. licheniformis MH31 was stable (75\%) up to $60^{\circ} \mathrm{C}$ after $1 \mathrm{~h}$ of incubation, whereas
Deng et al. (2010) found that enzyme retained about $40 \%$ of its initial activity at $60^{\circ} \mathrm{C}$ after $1 \mathrm{~h}$ of incubation in case of Bacillus sp. B001. The most commercially available subtilisin-type protease is also active at temperature ranging from 50 to $60^{\circ} \mathrm{C}$ (Ghorbel et al. 2003; Saeki et al. 2007). Interestingly alkaline protease from $B$. licheniformis P003 was found to be more stable at high temperatures when compared with previous findings.

All enzymes have optimum reaction time for showing its maximum catalytic activity. The enzyme exhibited its

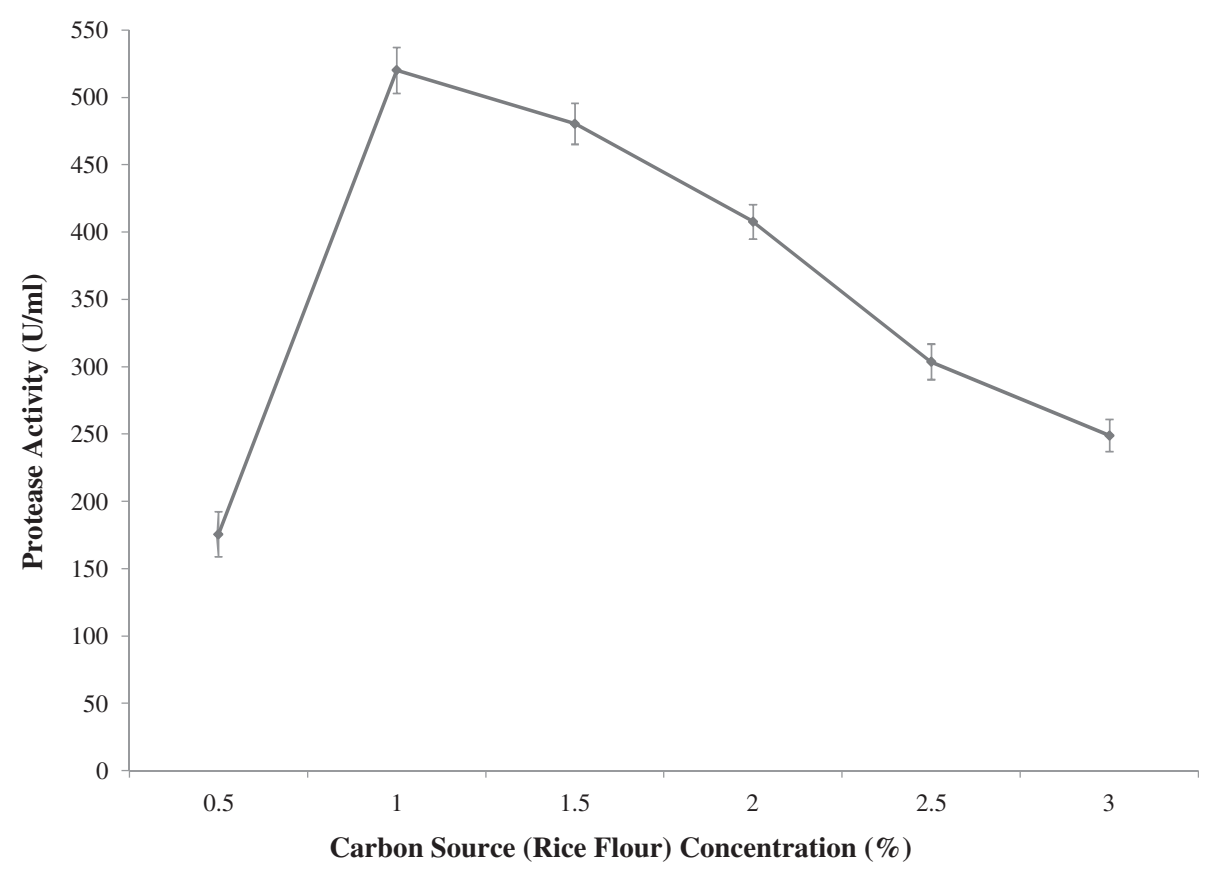

Figure 1 Effect of carbon source (rice flour) concentration on protease production by Bacillus licheniformis P-003. The effect of rice flour concentration on enzyme production was investigated by using $1 \%$ inoculum (w/v) in $100 \mathrm{ml}$ basal medium. The fermentation was carried out at $37^{\circ} \mathrm{C}$ at $150 \mathrm{rpm}$ for $48 \mathrm{~h}$. Absorbance was measured at $660 \mathrm{~nm}$ with spectrophotometer and enzyme activity was presented on the y axis and carbon source concentration was on $\mathrm{x}$ axis. Bars represent means \pm standard errors for three replicates. 
Table 3 Depicting the protease activity and total soluble protein of the culture supernatant of B. licheniformis P003 grown on different nitrogen source in presence of $1 \%$ glucose

\begin{tabular}{lccc}
\hline Nitrogen sources (\%) & Protease activity (U/ml) & Protease activity (U/mg) & Total protein content $(\mathbf{m g} / \mathbf{m l})$ \\
\hline Control (Peptone, 1\%) & $37.66 \pm 0.311$ & $25.61 \pm 0.48$ & $1.080 \pm 0.010$ \\
Tryptone (1\%) & $31.87 \pm 0.165$ & $20.49 \pm 0.88$ & $1.543 \pm 0.084$ \\
Yeast Extract (1\%) & $48.71 \pm 0.233$ & $44.06 \pm 0.08$ & $1.102 \pm 0.010$ \\
Beef Extract (1\%) & $191.23 \pm 0.229$ & $159.37 \pm 1.31$ & $1.190 \pm 0.026$ \\
P (0.5\%) + T (0.5\%) & $22.85 \pm 0.145$ & $13.67 \pm 0.67$ & $1.673 \pm 0.075$ \\
P (0.5\%) + YE (0.5\%) & $12.02 \pm 0.106$ & $8.85 \pm 0.20$ & $1.356 \pm 0.020$ \\
P (0.5\%) + BE (0.5\%) & $19.84 \pm 0.145$ & $18.30 \pm 0.15$ & $1.082 \pm 0.006$ \\
$T(0.5 \%)+$ YE (0.5\%) & $34.27 \pm 0.207$ & $17.47 \pm 0.16$ & $1.956 \pm 0.014$ \\
$T(0.5 \%)+B E(0.5 \%)$ & $21.64 \pm 0.229$ & $12.70 \pm 0.16$ & $1.700 \pm 0.009$ \\
$B E(0.5 \%)+Y E(0.5 \%)$ & $36.68 \pm 0.257$ & $30.40 \pm 0.36$ & $1.207 \pm 0.007$ \\
\hline
\end{tabular}

$\mathrm{P}=$ Peptone, $\mathrm{T}=$ Tryptone, $\mathrm{YE}=$ Yeast Extract, $\mathrm{BE}=$ Beef Extract, Data represent as mean \pm standard error (SE) for three replicates.

maximum activity at 70 min of reaction time (Figure 7). Stability of the enzyme is of great importance for the economy of their industrial application since highly purified enzyme preparations are expensive. Temperature is an important limiting factor for storage of enzymes. The present enzyme showed good storage stability at $4^{\circ} \mathrm{C}$ (Figure 8 ). About $66 \%$ of the activity retained up to 28 days when stored at $4^{\circ} \mathrm{C}$ whereas only $46 \%$ activity retained at room temperature $\left(30^{\circ} \mathrm{C}\right)$. When compared with control (stored at $4^{\circ} \mathrm{C}$ ), the enzyme showed reasonable storage stability at room temperature. The results are in accordance with Paul et al. (2007).

Different metal ions were used to determine effect of protease activity. $\mathrm{Mn}^{2+}$ and $\mathrm{Mg}^{2+}$ increased 31\% and 3\% of the residual activity respectively (Figure 9). $\mathrm{Ca}^{2+}$ had no significant effect on enzyme activity. However, $\mathrm{Fe}^{2+}$ and EDTA decreased the protease activity by $30.19 \%$ and $17 \%$ respectively. This result correlates with the findings of Sayem et al. (2006), who reported that $\mathrm{Mn}^{2+}$ and $\mathrm{Mg}^{2+}$ ion increased the protease activity by $39 \%$ and $31 \%$,

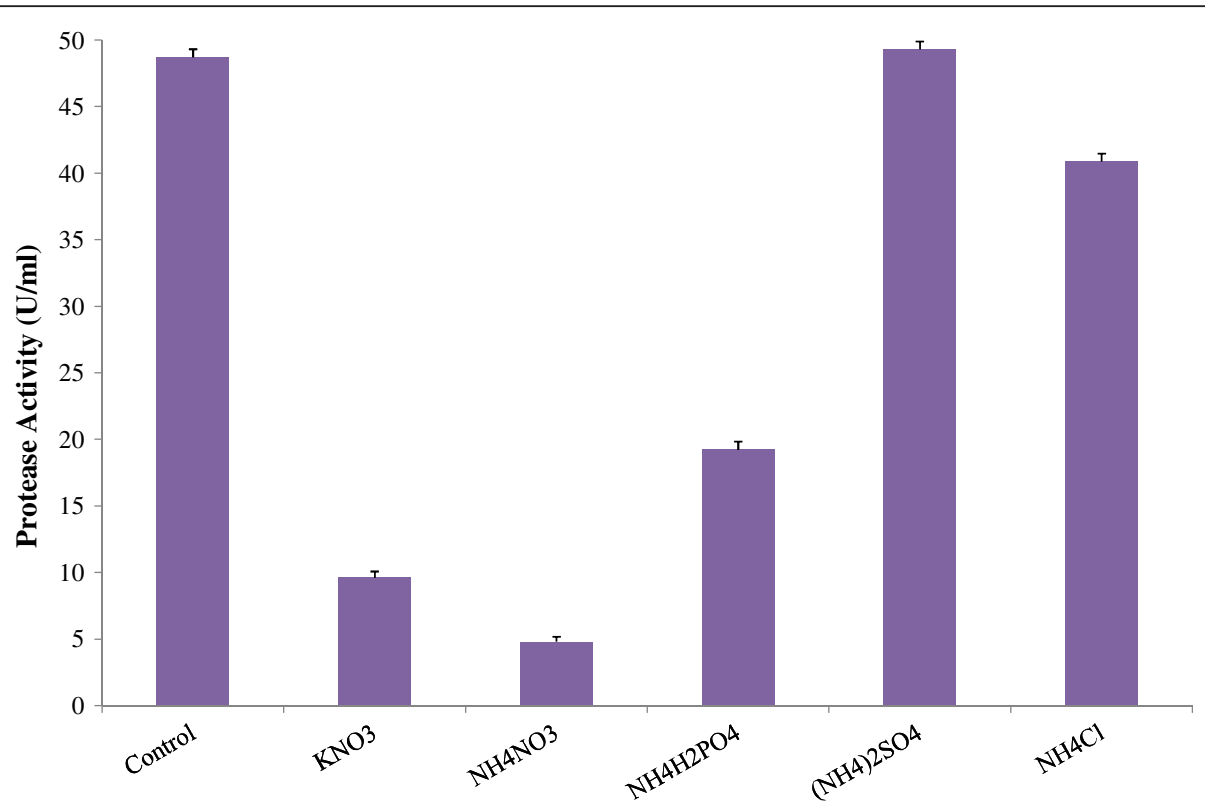

Inorganic Nitrogen Source

Figure 2 Effect of inorganic nitrogen source on protease production by Bacillus licheniformis P-003. To determine the effect of inorganic nitrogen sources on enzyme production, different inorganic nitrogen sources were used $(1.0 \% \mathrm{~W} / \mathrm{v})$ in $100 \mathrm{ml}$ of basal medium. The fermentation was carried out at $37^{\circ} \mathrm{C}$ at $150 \mathrm{rpm}$ for $48 \mathrm{~h}$. Bars represent means \pm standard deviations for three replicates. 


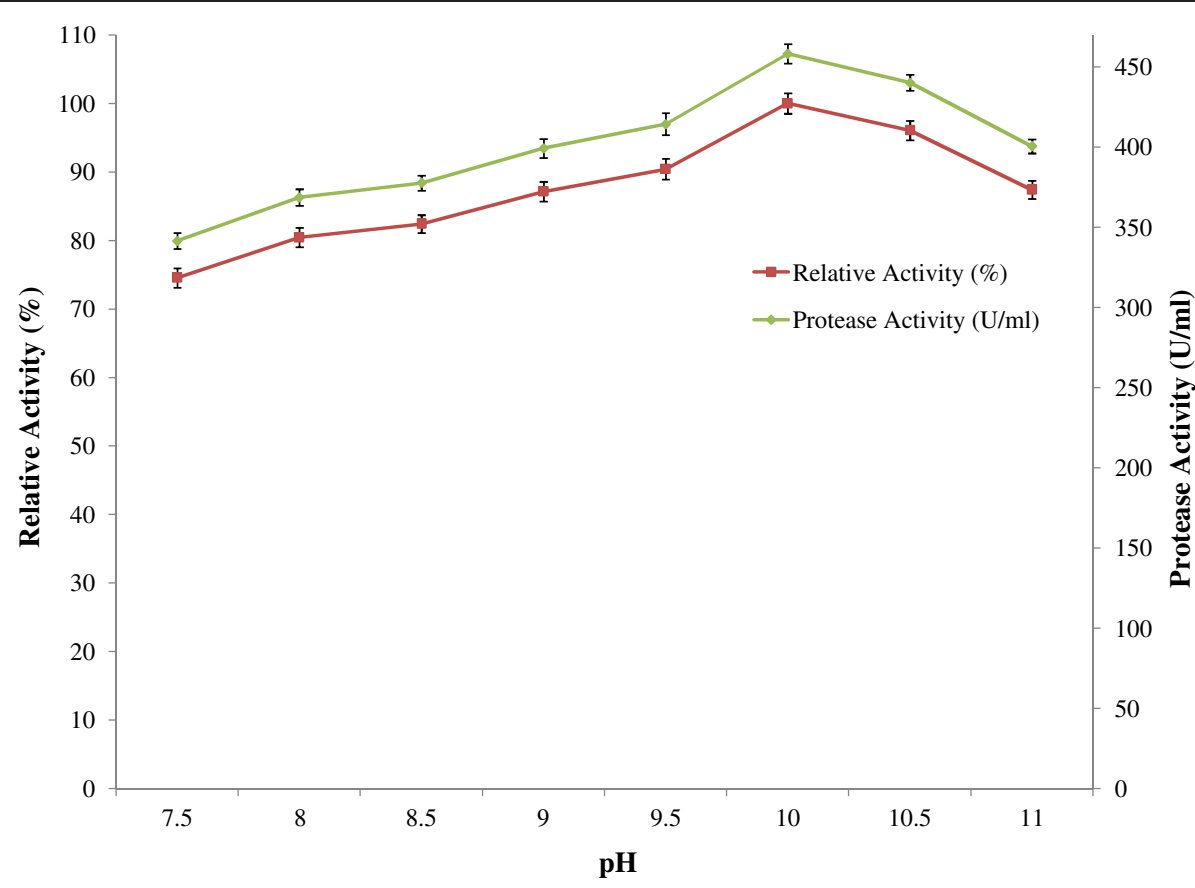

Figure 3 Effect of $\mathrm{pH}$ on protease activity. For determination of optimum assay pH of the enzyme reaction, $0.05 \mathrm{M} \mathrm{Na} \mathrm{Na}_{2} \mathrm{HPO}_{4}-\mathrm{NaH}_{2} \mathrm{PO}_{4}(\mathrm{pH} 6.5$ to 7.0), Tris- $\mathrm{HCl}\left(\mathrm{pH} 7.5\right.$ to 8.5) and Glycine- $\mathrm{NaOH}$ (pH 9.0 to 12) buffers were used. The reaction was carried out for 20 min at $50^{\circ} \mathrm{C}$ in shaking water bath. Enzyme activity was measured and the results were presented on graph. Bars represent means \pm standard deviations for three replicates.

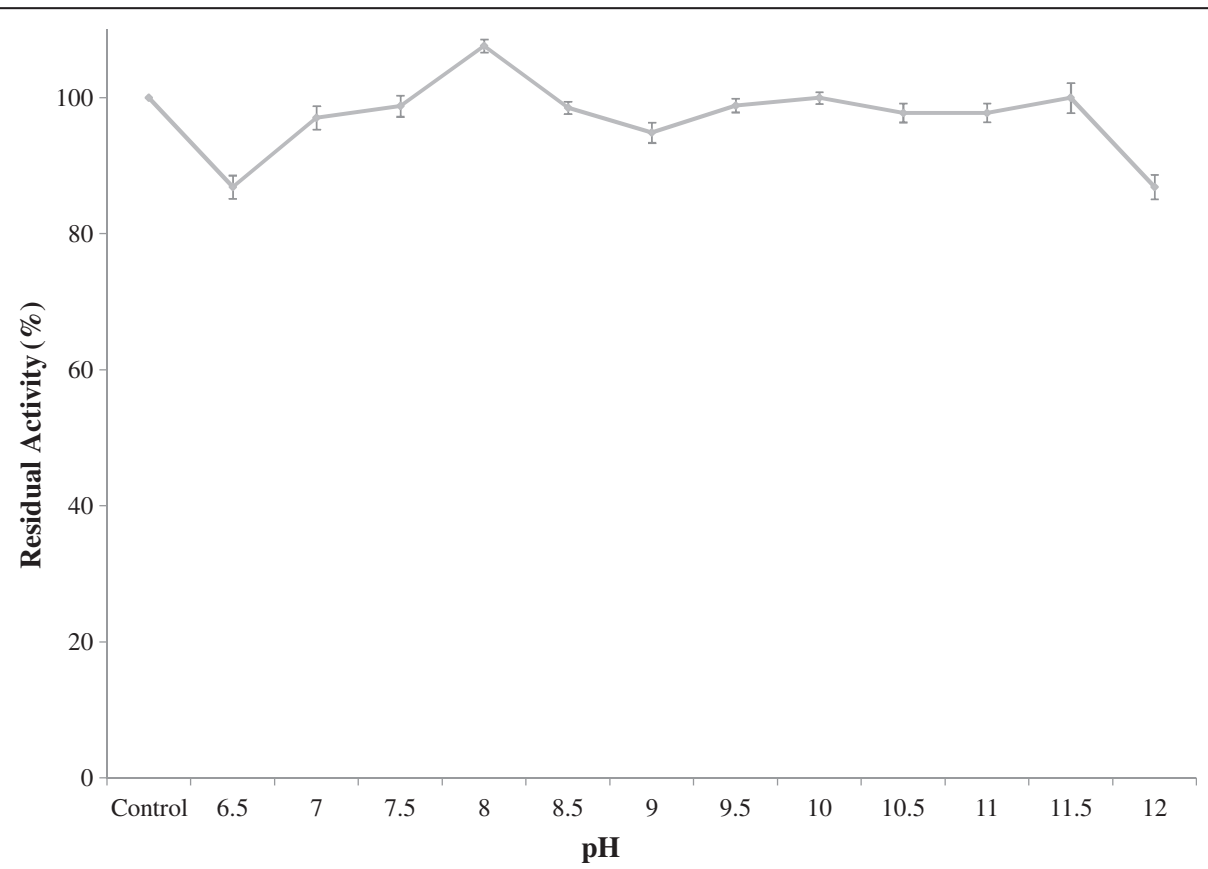

Figure 4 Effect of pH stability on protease activity. The effect of pH on the stability on protease was studied by pre-incubating the enzyme with $0.05 \mathrm{M}$ buffers covering the $\mathrm{pH}$ range of 6.5-12.0. $0.5 \mathrm{ml}$ enzyme samples were added to $1 \mathrm{ml}$ of different buffer and pre-incubated at $4^{\circ} \mathrm{C}$ for $24 \mathrm{~h}$. Then residual activity in each sample was determined by standard protease assay and compared with the control sample kept at $4^{\circ} \mathrm{C}$ without any buffer. Bars represent means \pm standard deviations for three replicates. 


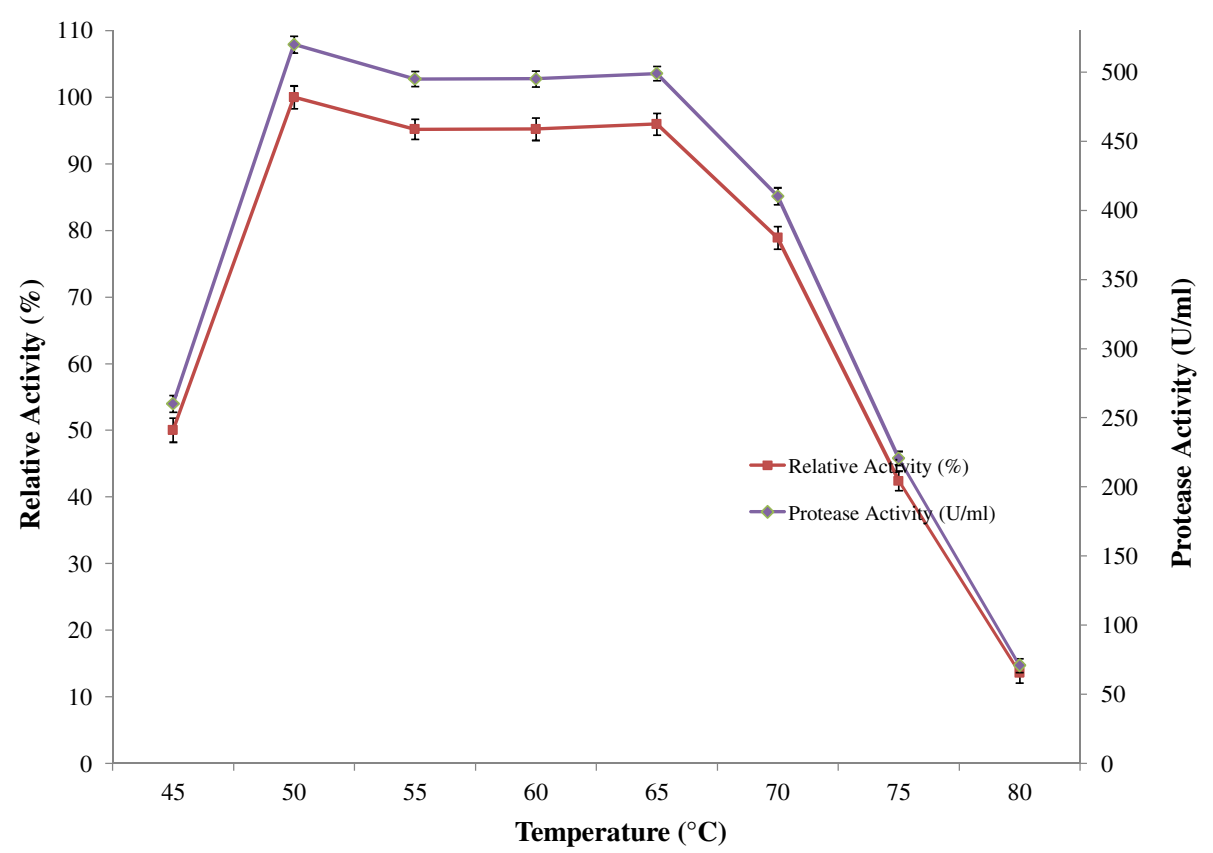

Figure 5 Effect of temperature on protease activity. To study the effect of temperature on enzyme reaction activity, enzyme reaction was carried out at different temperatures for $20 \mathrm{~min}$ in a shaking water bath and results are presented on graph. Bars represent means \pm standard deviations for three replicates.

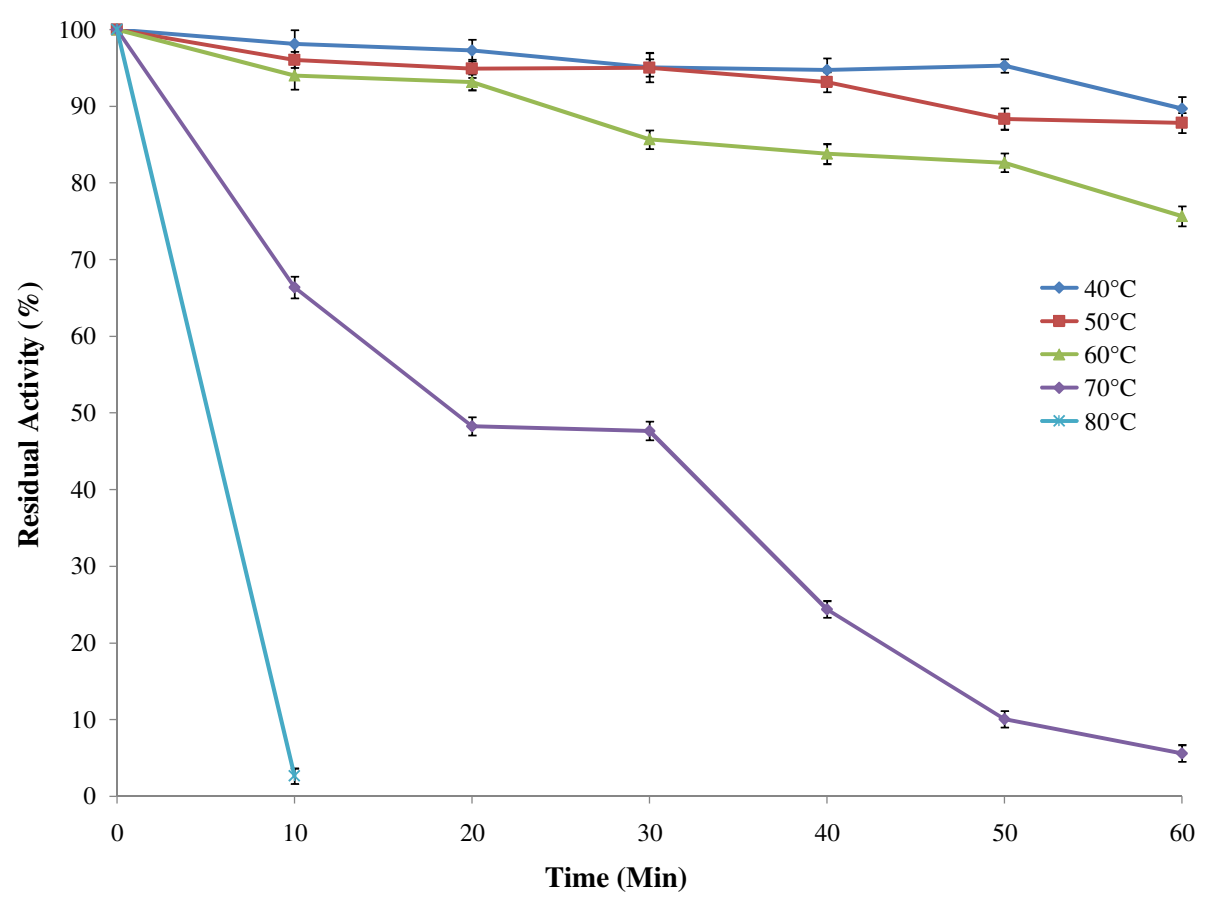

Figure 6 Effect of temperature on protease stability. For the determination of thermostability of protease, $0.5 \mathrm{ml}$ of enzyme solutions were pre heated at different temperatures for different time intervals in a shaking water bath. Then enzyme activity of the heat treated enzymes were then measured and the results are presented on graph. Bars represent means \pm standard deviations for three replicates. 


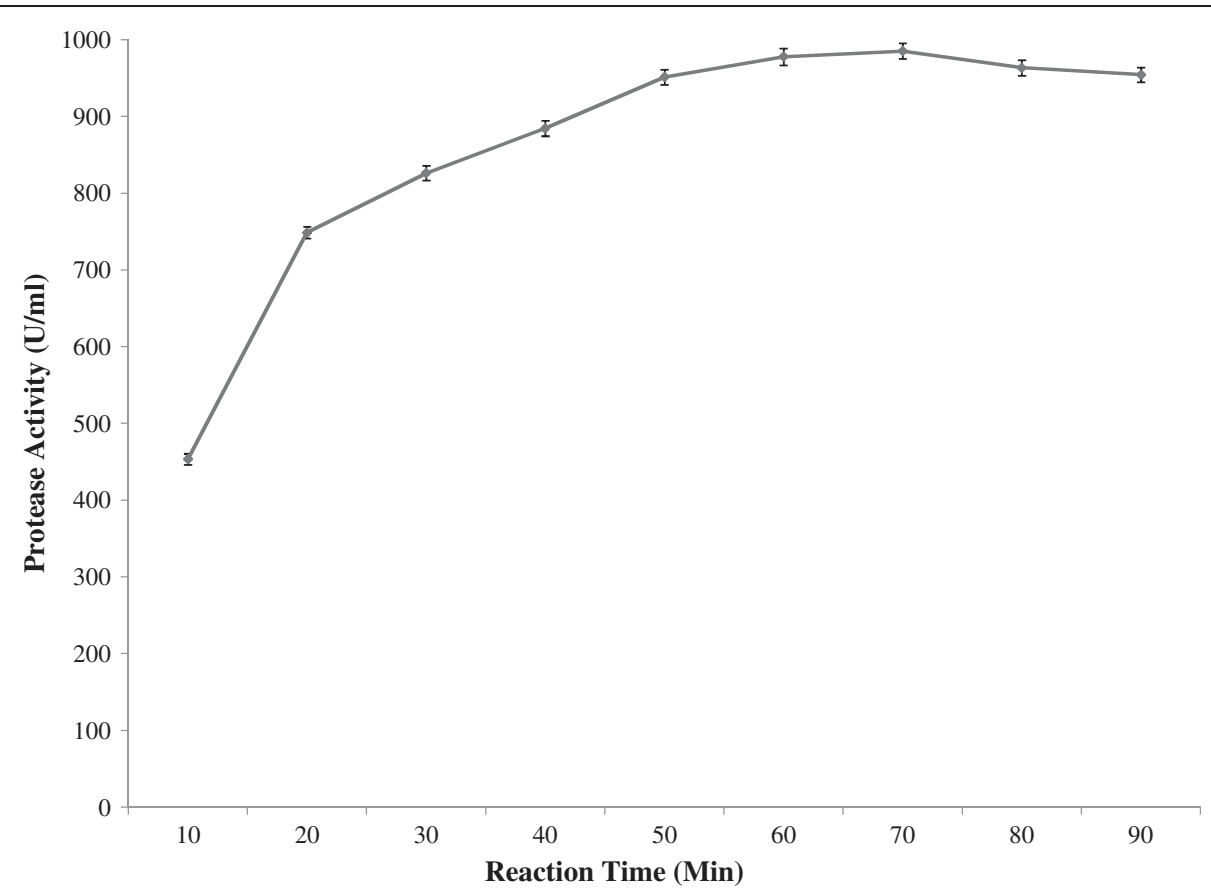

Figure 7 Effect of reaction time on enzyme activity.

respectively. $\mathrm{Yu}$ et al. (2006) also found that $\mathrm{Mn}^{2+}$ and $\mathrm{Ca}^{2+}$ marginally stimulated the alkaline protease from $B$. licheniformis MH31 up to $20 \%$ of the maximum activity.

Studies on the effects of various surfactants and oxidizing agents at different concentrations on protease activity revealed that upon incubation with Tween-20, Tween-80 and $\mathrm{H}_{2} \mathrm{O}_{2}$, the enzyme showed enhanced residual activities between $103-108 \%$, each at $0.5 \%$ concentration (Table 4). At $1 \%$ concentration of Tween-20 and $\mathrm{H}_{2} \mathrm{O}_{2}$, the enzyme retained $84 \%$ and $90 \%$ residual

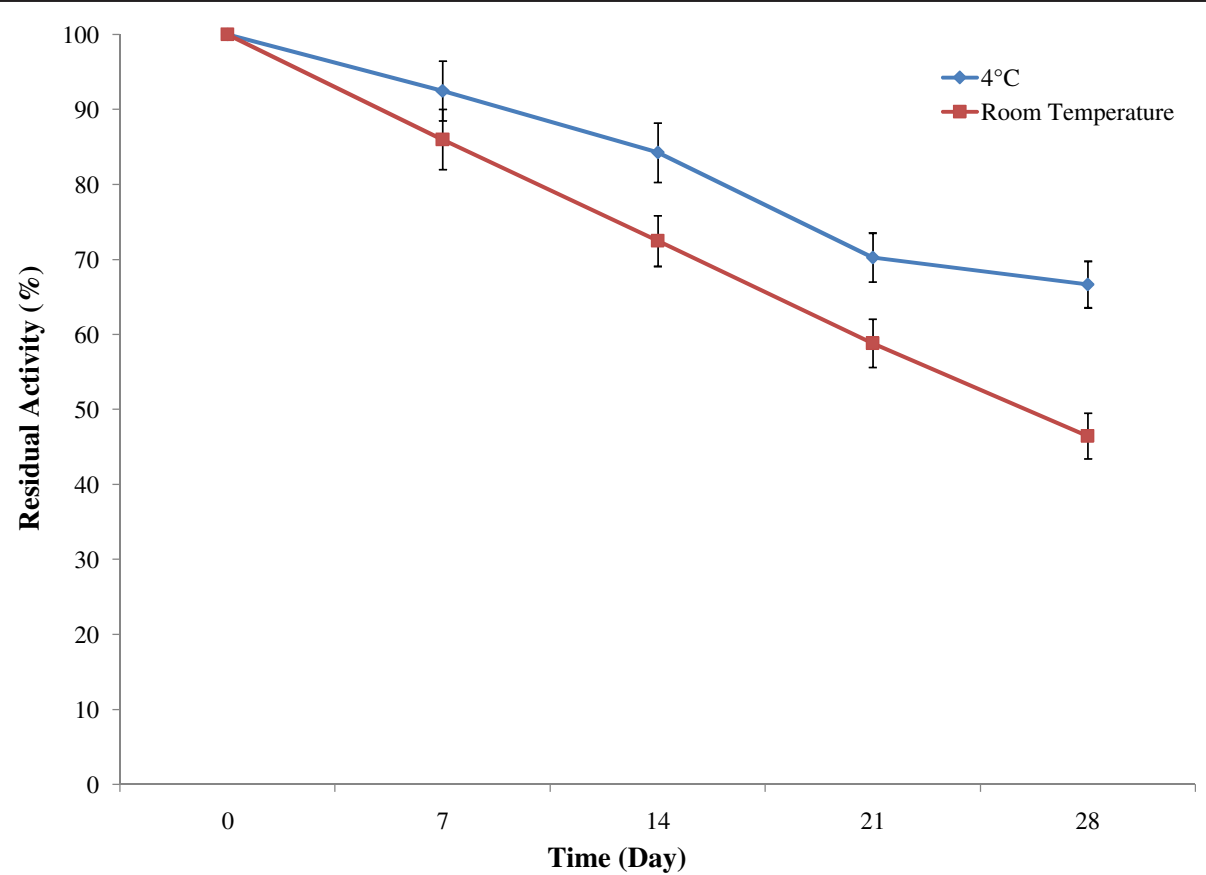

Figure 8 Effect of reaction time on enzyme activity. To investigate the optimum reaction time of the enzyme solution, reaction was carried out at $50^{\circ} \mathrm{C}$ in a water bath at different time intervals and the enzyme activity was then measured. The results are presented on graph. Bars represent means \pm standard deviations for three replicates. 


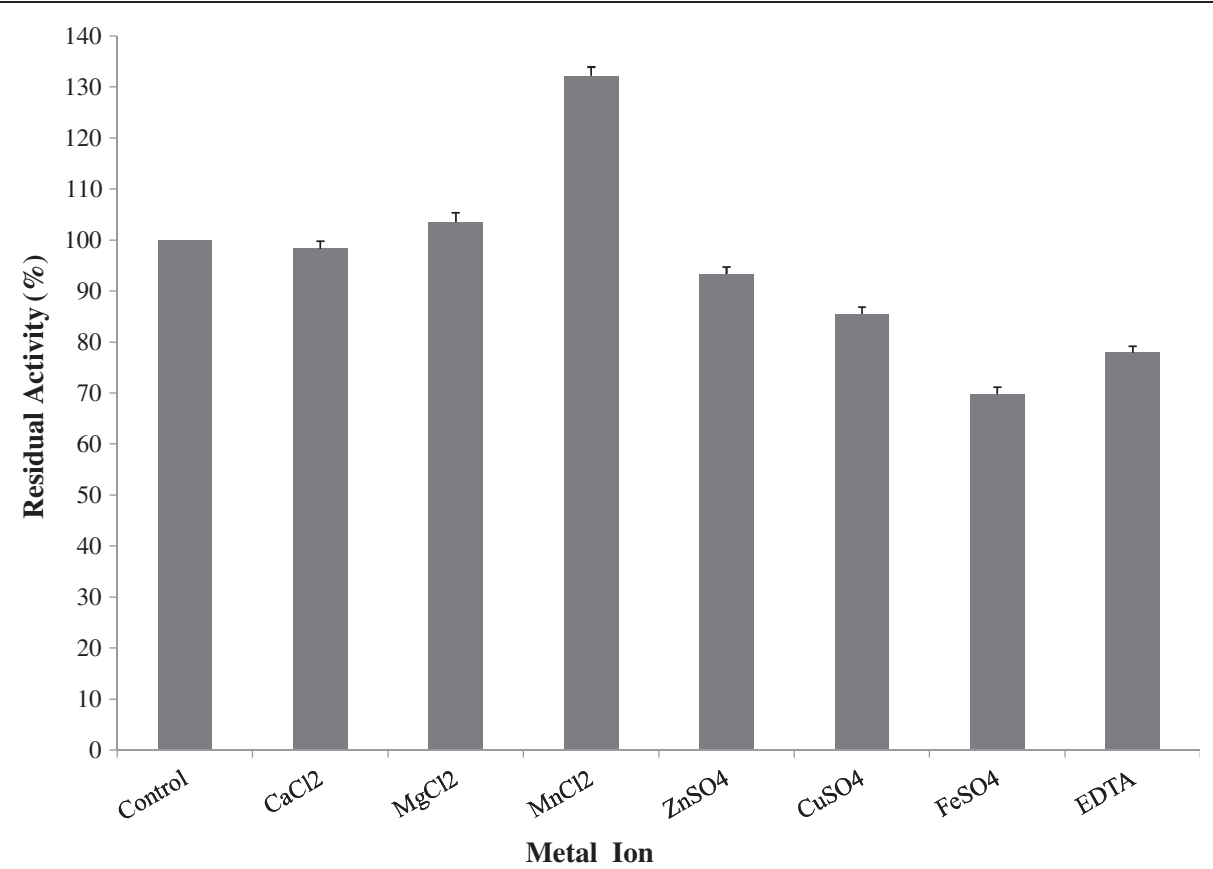

Figure 9 Effect of storage temperature on stability. To determine the storage stability of protease enzyme, crude enzyme solution was stored at $4^{\circ} \mathrm{C}$ and room temperature. Enzyme activity was measured at 7 days interval over 28 days by standard assay method described previously. The results are presented on graph. Bars represent means \pm standard deviations for three replicates.

activity. But in case of Tween-80, both $0.5 \%$ and $1 \%$ concentrations increased the protease activity up to $107 \%$ and 104\%, respectively. Enzyme sharply lost its residual activity in the presence of SDS to $16 \%$ and $11 \%$ at a concentration of $0.5 \%$ and $1.0 \%$ respectively. The protease activity was decreased gradually as the concentration of Tween-20 and $\mathrm{H}_{2} \mathrm{O}_{2}$ increases.

\section{Conclusion}

The results in this study indicated that optimization of culture conditions played a central role for improving yield through the shake flask fermentation process. Maximum protease activity was obtained after optimization of the nutritional components and fermentation processes.
Along with production optimization, this work also describes the partial characterization of alkaline protease from B. licheniformis P003. These characteristics indicated that alkaline protease produced by $B$. licheniformis $\mathrm{P} 003$ might be an excellent candidate for use as detergent additive in laundry industry and as a dehairing and bating agent in tanneries. Further studies on protease produced by $B$. licheniformis P003 would make it feasible for commercialization of the enzyme.

\section{Materials and methods Microorganism}

The bacterial culture B. licheniformis P-003 was obtained from the Microbial Biotechnology Division, National

Table 4 Effect of surfactants and oxidants on protease stability

\begin{tabular}{cccc}
\hline Surfactants/ oxidizing agent & Concentration (\%) & Activity (U/ml) & Residual activity (\%) \\
\hline Tween-20 & 0.5 & $497.33 \pm 0.141$ & 103.37 \\
\multirow{2}{*}{ Tween-80 } & 1.0 & $407.13 \pm 0.132$ & 84.62 \\
& 0.5 & $515.37 \pm 0.104$ & 107.12 \\
$\mathrm{SDS}$ & 1.0 & $503.43 \pm 0.195$ & 104.64 \\
& 0.5 & $78.78 \pm 0.210$ & 16.37 \\
$\mathrm{H}_{2} \mathrm{O}_{2}$ & 1.0 & $52.92 \pm 0.132$ & 11.00 \\
& 0.5 & $520.79 \pm 0.195$ & 108.25 \\
Control & 1.0 & $435.99 \pm 0.235$ & 90.62 \\
\hline
\end{tabular}

Data represent as mean \pm standard error (SE) for three replicates. 
Institute of Biotechnology, Ganakbari, Savar, Dhaka. Stock culture of the organism was maintained on nutrient agar medium at $4^{\circ} \mathrm{C}$ in refrigerator for routine laboratory use and $15 \%$ glycerol broth at $-20^{\circ} \mathrm{C}$ for long term preservation.

\section{Preparation of seed culture}

Vegetative inoculums were used in the present studies. $50 \mathrm{ml}$ of inoculums medium containing nutrient broth $13 \mathrm{~g} / \mathrm{l}, \mathrm{pH} 7.4 \pm 0.2$ was transferred to a $100 \mathrm{ml}$ conical flask and cotton plugged. It was sterilized in an autoclave at $15 \mathrm{lbs} / \mathrm{inch}^{2}$ pressure at $121^{\circ} \mathrm{C}$ for $20 \mathrm{~min}$. After cooling to room temperature, a loopful of freshly grown culture was aseptically transferred to it. The flask was incubated overnight at $37^{\circ} \mathrm{C}$ and $150 \mathrm{rpm}$ in a rotary shaking incubator.

\section{Fermentation and separation of culture filtrates}

The seed culture $(1 \mathrm{ml})$ was transferred to $100 \mathrm{ml}$ of basal medium in a 250-ml Erlenmeyer flask. Basal medium contained Glucose $10.0 \mathrm{~g} / \mathrm{l}$, Peptone $10.0 \mathrm{~g} / \mathrm{l}$, $\mathrm{K}_{2} \mathrm{HPO}_{4} 1.0 \mathrm{~g} / \mathrm{l}, \mathrm{MgSO}_{4} 0.2 \mathrm{~g} / \mathrm{l}, \mathrm{Na}_{2} \mathrm{CO}_{3} 5.0 \mathrm{~g} / \mathrm{l}$ (initial $\mathrm{pH}$ 10.0). The inoculated flasks were placed in a thermostated orbital shaker for 48 hours, at $37^{\circ} \mathrm{C}$ and $150 \mathrm{rpm}$. Samples were withdrawn at regular intervals and centrifuged in a refrigerated centrifuge machine at $10000 \mathrm{rpm}$ for 15 minutes at $4^{\circ} \mathrm{C}$. The cell free supernatant was preserved at $4^{\circ} \mathrm{C}$ and used for enzyme assay and protein estimation.

\section{Soluble protein estimation}

Extracellular soluble protein in culture filtrate was estimated by Lowry's method using bovine serum albumin (BSA) used as Standard (Lowry et al. 1951). $2 \mathrm{ml}$ of analytical reagent was added to $0.2 \mathrm{ml}$ suitably diluted test samples (enzyme solution). The mixture was mixed well and allowed to stand for $10 \mathrm{~min}$ at $50^{\circ} \mathrm{C}$. Then $0.2 \mathrm{ml}$ of the folin-ciocalteau reagent was added and shaken to mix well and incubated at room temperature for about 30 min. Optical density of the reaction mixture was measured at $600 \mathrm{~nm}$, against a blank prepared with 0.2 $\mathrm{ml}$ buffer. A standard curve was constructed with each experiment using bovine serum albumin as a known protein. The amount of the soluble protein was calculated from the standard curve as $\mathrm{mg}$ protein per $\mathrm{ml}$ of test samples.

\section{Determination of enzyme activity}

Protease activity was determined by Anson method (Anson, 1938; Bhunia et al., 2010) using 1\% casein as substrate. $0.2 \mathrm{ml}$ of enzyme solution was added to $0.8 \mathrm{ml}$ of substrate solution $(1 \% \mathrm{~V} / \mathrm{V}$, casein with $50 \mathrm{mM}$ Glycine- $\mathrm{NaOH}$ buffer, $\mathrm{pH} 10.0$ ) and incubated at $50^{\circ} \mathrm{C}$ for 20 min independently with respective controls. The reaction was stopped by adding $1 \mathrm{ml}$ of $10 \%$ TCA followed by holding $10 \mathrm{~min}$ at room temperature and then subsequently followed by centrifugation at 8000 rpm for $15 \mathrm{~min}$ at $4^{\circ} \mathrm{C}$. After that $1 \mathrm{ml}$ of supernatant was added to $3 \mathrm{ml}$ of $0.4 \mathrm{M} \mathrm{Na}_{2} \mathrm{CO}_{3}$ solution. Then 0.5 $\mathrm{ml}$ of Folin reagent was immediately added to each tube, vortexed and left for $30 \mathrm{~min}$ at room temperature. This provides coloration (measured at $\mathrm{OD}_{660} \mathrm{~nm}$ ) equivalent to $1 \mu \mathrm{mol}$ of tyrosine, in the presence of the FolinCiocalteau reagent by using a tyrosine standard curve (Folin and Ciocalteu 1927). The protease activity was expressed as the difference of absorbance at $660 \mathrm{~nm}$ between the control and the test sample. One unit of protease activity was defined as the amount of enzyme liberating $1 \mu \mathrm{g}$ of tyrosine/min under assay conditions. Enzyme units were measured using tyrosine $(0-100 \mathrm{mg})$ as standard.

\section{Optimization of fermentation parameters}

The fermentation condition for protease production by B. licheniformis P003 was studied. The experiments were carried out systematically in such a way that the parameter optimized in one experiment was maintained at its optimum level in the subsequent experiments. Various process parameters that enhance the yield of protease under submerged fermentation were investigated by taking one factor at a time. The impact of initial $\mathrm{pH}$ (8.0-11.0), temperature $\left(32-45^{\circ} \mathrm{C}\right)$, incubation time (24$120 \mathrm{~h}$ ), inoculums concentration (0.5-3.5\%) and medium composition (carbon, organic and inorganic nitrogen) were evaluated. All the experiments were conducted in triplicate and then the mean values were considered.

\section{Statistical analysis}

Data analysis was performed using SPSS software version 10 (Chicago, USA). The results were presented as mean $\pm \mathrm{SE}$.

\section{Competing interests}

The authors declare that they have no competing interests.

\section{Authors' contributions}

PKS planned the work and analyzed the experimental data that led to the manuscript; SA produced and analyzed the experimental data; PD and KM participated in the interpretation of the results; PD, SA, KM, SMAS and PKS wrote the paper. All authors read and approved the final manuscript.

\section{Author details}

${ }^{1}$ Microbial Biotechnology Division, National Institute of Biotechnology, Savar, Dhaka, Bangladesh. ${ }^{2}$ Department of Genetic Engineering and Biotechnology, Shahjalal University of Science and Technology, Sylhet, Bangladesh.

Received: 20 May 2013 Accepted: 18 September 2013

Published: 4 October 2013

\section{References}

Akcan N (2012) Production of extracellular protease in submerged fermentation by Bacillus licheniformis ATCC 12759. Afr J Biotechnol 11(7):1729-1735 
Anson ML (1938) The estimation of pepsin, trypsin, papain and cathepsin with hemoglobin. J Gen Physiol 22:79-89

Anwar A, Saleemuddin M (2000) Alkaline protease from Spilosoma obliqua: potential applications in bio-formulations. Biotechnol Appl Biochem 3192:85-89

Beg QK, Saxena RK, Gupta R (2002) De-repression and subsequent induction of protease synthesis by Bacillus mojavensis under fed-batch operations. Process Biochem 37(10):1103-1109

Bhunia B, Dutta D, Chaudhuri S (2010) Selection of suitable carbon, nitrogen and sulphate source for the production of alkaline protease by Bacillus licheniformis NCIM-2042. Not Sci Biol 2(2):56-59

Bhunia B, Dutta D, Chaudhuri S (2011) Extracellular alkaline protease from Bacillus licheniformis NCIM-2042: improving enzyme activity assay and characterization. Engineering in Life Sciences 11(2):207-215

Deng A, Wu J, Zhang Y, Zhang G, Wen T (2010) Purification and characterization of a surfactant-stable high-alkaline protease from Bacillus sp. B001. Bioresour Technol 101:7100-7116

Feng YY, Yang WB, Ong SL, Hu JY, Ng WJ (2001) Fermentation of starch for enhanced alkaline protease production by constructing an alkalophilic Bacillus pumilus strain. Appl Microbiol Biotechnol 57:153-160

Folin O, Ciocalteu V (1927) On tyrosine and tryptophan determination in proteins. J Biol Chem 73:627-650

Fu Z, Hamid SBA, Razak CNA, Basri M, Bakar Salleh A, Rahman RNZA (2003) Secretory expression in Escherichia coli and single-step purification of a heat-stable alkaline protease. Protein Expr Purif 28(1):63-68

Genckal H, Tari C (2006) Alkaline protease production from alkalophilic Bacillus sp. isolated from natural habitats. Enzyme Microb Technol 39:703-710

Ghorbel B, Sellami-Kamoun A, Nasri M (2003) Stability studies of protease from Bacillus cereus BG1. Enzyme Microb Technol 32:513-518

Gupta R, Beg QK, Khan S, Chauhan B (2002) An overview on fermentation, downstream processing and properties of microbial alkaline proteases. Appl Microbiol Biotechnol 60(4):381-395

Haki GD, Rakshit SK (2003) Developments in industrially important thermostable enzymes: a review. Bioresour Technol 89(1):17-34

Hossain MS, Azad AK, Sayem SMA, Mostafa G, Hoq MM (2007) Production and partial characterization of feather degrading keratinolytic serine protease from Bacillus licheniformis MZK-3. J Biol Sci 7(4):599-606

Johnvesly B, Naik GR (2001) Studies on production of thermostable alkaline protease from thermophilic and alkaliphilic Bacillus sp. JB-99 in a chemically defined medium. Process Biochem 37(2):139-144

Joo HS, Kumar CG, Park GC, Paik SR, Chang CS (2003) Oxidant and SDS-stable alkaline protease from Bacillus clausii 1-52: production and some properties. J Appl Microbiol 95:267-272

Kumar CG, Takagi H (1999) Microbial alkaline proteases: from a bioindustrial viewpoint. Biotechnol Advances 17:561-594

Lowry OH, Rosebrough NJ, Farr AL, Randall RJ (1951) Protein measurement with the Folin phenol reagent. J Biol Chem 193(1):265-75

Mabrouk SS, Hashem AM, El-Shayeb NMA, Ismail AS, Abdel-Fattah AF (1999) Optimization of alkaline protease productivity by Bacillus licheniformis ATCC 21415. Bioresour Technol 69:155-159

Nadeem M, Shahjahan B, Syed QA (2006) Microbial production of alkaline proteases by locally isolated Bacillus subtilis PCSIR-5. Pak J Zool 38:109-118

Nadeem M, Qazi JI, Baig S, Syed Q (2008) Effect of medium composition on commercially important alkaline protease production by Bacillus licheniformis N-2. Food Technol Biotechnol 46(4):388-394

Naidu KSB, Devi KL (2005) Optimization of thermostable alkaline protease production from species of Bacillus using rice bran. Afr J Biotechnol 4(7):724-726

Nejad ZG, Yaghmaei S, Hosseini RH (2009) Production of extracellular protease and determination of optimal condition by Bacillus licheniformis BBRC 100053. IJE Transactions B: Applications 22(3):221-228

Olajuyigbe FM, Ajele JO (2008) Some properties of extracellular protease from Bacillus licheniformis lbbl-11 isolated from "iru", a traditionally fermented African locust bean condiment. Global J Biotechno Biochem 3(1):42-46

Pandey A, Nigam P, Soccol CR, Soccol VT, Singh D, Mohan R (2000) Advances in microbial amylases. Biotechnol Appl Biochem 1:135-152

Paul D, Rahman A, llias M, Hoq M (2007) Production and characterization of keratinolytic protease of Bacillus licheniformis MZK-03 grown on feather mill. Bangladesh J Microbiol 24(1):57-61

Puri S, Beg QK, Gupta R (2002) Optimization of alkaline protease production from Bacillus sp. by response surface methodology. Cur Micobiol 44:286-290
Rahman RNZA, Geok LP, Basri M, Salleh AB (2006) An organic solvent-stable alkaline protease from Pseudomonas aeruginosa strain K: enzyme purification and characterization. Enzyme Microb Technol 39(7):1484-1491

Reddy LVA, Wee YJ, Yun JS, Ryu HW (2008) Optimization of alkaline protease production by batch culture of Bacillus sp. RKY3 through plackett-burman and response surface methodological approaches. Bioresour Technol 99:2242-2249

Saeki KS, Katsuya O, Tohru K, Susumu I (2007) Detergent alkaline proteases: Enzymatic properties, genes, and crystal structures. J Biosci Bioeng 103:501-508

Sayem SMA, Alam MJ, Hoq MM (2006) Effect of temperature, pH and metal ions on the activity and stability of alkaline protease from novel Bacillus licheniformis MKZ03. Proc Pakistan Acad Sci 43(4):257-262

Srividya S, Mala M (2011) Influence of process parameters on the production of detergent compatible alkaline protease by a newly isolated Bacillus sp. Y. Turk J Biol 35:177-182

Xiong $Y$, Wang $Y, Y u$ Y, Li Q. Wang $H$, Chen $R$, He N (2010) Production and characterization of a novel bioflocculant from Bacillus licheniformis. Appl Environ Microbiol 76(9):2778-2782

Yu J, Jin H, Choi W, Yoon M (2006) Production and characterization of an alkaline protease from Bacillus licheniformis MH31. Agric Chem Biotechnol 49:135-139

doi:10.1186/2193-1801-2-506

Cite this article as: Sarker et al:: Optimization and partial

characterization of culture conditions for the production of alkaline protease from Bacillus licheniformis P003. SpringerPlus 2013 2:506.

\section{Submit your manuscript to a SpringerOpen ${ }^{\circ}$ journal and benefit from:}

- Convenient online submission

$\checkmark$ Rigorous peer review

- Immediate publication on acceptance

- Open access: articles freely available online

- High visibility within the field

- Retaining the copyright to your article

Submit your next manuscript at springeropen.com 